\title{
Does Type II diabetes mellitus affect bone turn-over markers in premenopausal women? A single center experience
}

\section{Tip II diyabetes mellitusun premenapozal kadınlarda kemik turnover belirteçleri üzerine etkisi, tek merkez deneyimi}

\author{
*Neyran Kertmen ${ }^{1}$, Mehmet Yıldız ${ }^{1}$ \\ ${ }^{1}$ Internal Medicine Clinic, The Ministry of Health Dışkapı Yıldırım Beyazıt Education And Research Hospital, Ankara, \\ Turkey \\ Corresponding author: Dr. Neyran Kertmen, İç Hastalıkları Kliniği, Sağılı Bakanlığı Dışkapı Yıldırım Beyazıt Eğitim ve \\ Araştırma Hastanesi, TR 06330 Ankara, Türkiye \\ E-mail: neyran_kertmen@yahoo.com \\ Received/Accepted: December 21, 2015/December 23, 2015 \\ Conflict of interest: There is not a conflict of interest.
}

\section{SUMMARY}

Objective: Diabetes mellitus (DM) is known to cause osteoporosis in premenopausal women with type II DM. The aim of this study was to show changes in bone turnover markers in diabetic premenopausal women.

Methods: Ninety-two women treated for type 2 DM and a control group of 33 women without diabetes were evaluated in terms of bone mineral density, osteocalcin, c-terminal telopeptide of type I collagen and homocysteine levels. Demographic data including body mass index, age and smoking status were recorded in both the patient and control groups. DM regulation was classified according to the European Association for the Study of Diabetes database (EASD).

Results: Age, BMI, smoking and duration of disease did not affect BMD or bone turnover markers. When the treatment modalities were evaluated, laboratory analysis revealed abnormal osteocalcin levels in patients using oral antidiabetics $(p=0.006)$. Homocysteine levels were abnormal in the diabetic group compared to the control group $(\mathrm{p}=0.018)$.

Conclusion: Our results demonstrate that DM adversely affected femoral BMD and bone turnover markers such as homocysteine. Some DM pharmacotherapies have side-effects on markers such as osteocalcin. Although some reports in the literature have suggested that the regulation of DM may affect the risk of osteoporosis, our results do not support that idea.

Keywords: Osteoporosis, Type 2 Diabetes Mellitus, bone turnover markers, bone densitometry

\section{ÖZET}

Amaç: Tip 2 diyabeti olan premenapozal bayanlarda diyabetin osteoporoza zemin hazırlayan bir antite olduğu bilinmektedir. Bu çalıșmada amaç kemik turnover belirteçlerindeki değișimin gösterilmesidir.

Yöntem: Calıșmamızda Tip 2 diyabet tanısı ile izlenen 92 kadın hasta ve 33 diyabeti olmayan kontrol grubu demografik veriler toplandıktan sonra kemik mineral dansitesi (KMD) belirlenip, osteokalsin (OC), c terminal tip I kollagen (CTX) ve homosistein (HCY) düzeyleri ölçüldü. Diyabetik hastalar DM regülasyon durumuna gore sinıflandırıldı (European Association for the Study of Diabetes (EASD) verilerine göre)

Sonuç: Yaș, vücut kitle indeksi (BMI) ve sigara içimi, hastalık süresi gibi paremetrelerin kemik turnover belirteçleri ve KMD üzerine etkisi saptanmadı. Diyabetik grupta homosistein düzeyi kontrol grubuna göre anormal olarak saptand $1(p=0,018)$. Tedavi modaliteleri incelendiğinde oral antidiyabetik alanların osteokalsin düzeyleri düşük saptandı $(p=0,006)$.

Tartışma: Sonuç olarak çalışmamızda DM hastalarında femur KMD değerlerinin ve homosistein gibi kemik turnover markırlarının olumsuz etkilendiği görülmüştür. Literatürde diyabet regülasyonunun osteoporoz riskini etkilediğine dair yayınlar olsa da çalışmamızda bu konuda anlamlı sonuç saptanmamıștır.

Anahtar sözcükler: Osteoporoz, Tip 2 Diyabetes Mellitus, kemik turnover belirteçleri, kemik dansitometrisi 


\section{INTRODUCTION}

The relationship of diabetes mellitus (DM) and osteoporosis is complex, and the pathogenesis of diabetic osteopenia is still unknown. Type 2 DM and healthy populations have previously been compared in terms of bone mineral density, with high$\mathrm{er}^{1}$, equal ${ }^{2}$ or lower ${ }^{3}$ levels being reported. In recent studies, despite high bone mineral density (BMD) measurements, type 2 $\mathrm{DM}$ has been reported to be a risk factor for fractures of the proximal humerus, hip and foot $^{4}$. The risk of fracture is influenced by numerous factors, such as duration of disease, body mass index (BMI) and medical treatment ${ }^{5}$. The purpose of this study was to show changes in bone turnover markers in premenopausal diabetic women, even if osteoporosis is not determined.

Bone turnover markers generally reveal different stages of bone turnover in a fast, sensitive and dynamic way. These markers are divided into 3 categories, indicating the number of osteoblasts, bone formation or resorption ${ }^{6}$. Bone turnover markers are used to determine the response to osteoporosis treatment and risk of fracture independently of bone mineral density. After treatment of osteoporosis, bone turnover markers increase before bone mineral density. Osteocalcin (OC) is a specific and sensitive marker of bone formation. C terminal type I collagen (CTX) is an independent risk factor for bone fractures and provides important information regarding quality. Homocysteine, a metabolite of Lmethionine amino acids is another marker related to collagen cross-linking. A homocysteine value $>15 \mathrm{mmol} / \mathrm{L}$ is associated with an approximately 2.5 -fold increased risk of bone fracture.

\section{MATERIALS AND METHODS}

Ninety-two premenopausal Type 2 diabetic women under monitoring at the Ministry of Health Dışkapı Yıldırım Beyazıt Education and Research Hospital internal medicine clinic, Turkey, and 33 healthy female volunteers were enrolled in the study.

Demographic data (age, BMI, smoking status and diabetic complications) were recorded. Bone turnover markers [homo- cysteine, osteocalcin and $\mathrm{C}$ terminal type I collagen (CTX)] and bone mineral densitometry were measured and compared between the study and control groups.

\section{Statistical analysis}

All analyses were performed using twosided P values. Differences between categoric variables were analyzed using Pearson's Chi-square test, and those between continuous variables using the independent t-test or one-way ANOVA where applicable. Statistical differences between groups were analyzed using the log-rank test. Analyses were performed on Statistical Package for the Social Sciences (SPSS, version 22) software. Differences were regarded as significant at $\mathrm{p}<0.05$.

\section{RESULTS}

\section{Demographic data}

Demographic data are shown in Table 1. Duration of diabetes was 5 years in $45 \%$ of patients, 5-9 years in 23\%, 10-14 years in $19 \%$ and $>15$ years in $8 \%$.

Of the patients in the study, $4.3 \%$ were receiving a diabetic diet, $51.1 \%$ were being treated with oral antidiabetics (OAD), 12\% were receiving insulin and $32.6 \%$ were receiving insulin and OAD. The microvascular complications retinopathy, neuropathy and nephropathy were documented in $26.3 \%, 29.3 \%$ and $3.3 \%$ (stage 1-3) of diabetic patients, respectively. Regulation status of DM was classified based on the European Association for the Study of Diabetes (EASD) database. Accordingly, $20.7 \%$ of patients had good regulation, $43.5 \%$ moderate and $35.9 \%$ insufficient.

Table 1: Demographic data.

\begin{tabular}{l|ll|l}
\hline Variables & Control group & $\begin{array}{l}\text { Patients } \\
(\mathbf{n = 9 2})\end{array}$ & $\mathbf{p}$ \\
\hline Age & & & $\mathbf{0 . 0 3 4}$ \\
30-39 years & $39.4 \%$ & $16.3 \%$ & 0.006 \\
40-44 years & $27.3 \%$ & $26.1 \%$ & 0.895 \\
45-49 years & $24.2 \%$ & $39.1 \%$ & 0.124 \\
50-55 years & $9.1 \%$ & $18.5 \%$ & 0.207 \\
\hline Body mass & & & $\mathbf{0 . 0 6 6}$ \\
index & & & \\
Normal & $9.1 \%$ & $7.6 \%$ & \\
Overweight & $42.4 \%$ & $23.9 \%$ & \\
Obese & $48.5 \%$ & $62.0 \%$ & \\
Morbidly obese & - & $6.5 \%$ & \\
\hline Smoking status & & & $\mathbf{0 . 2 4 4}$ \\
No & $84.8 \%$ & $75.0 \%$ & \\
Yes & $15.2 \%$ & $25.0 \%$ & \\
\hline
\end{tabular}


Table 2: Comparison of demographic status of high and normal CTX groups in DM patients.

\begin{tabular}{|c|c|c|c|}
\hline Variables & Normal & High & p \\
\hline $\begin{array}{l}\text { Age } \\
30-39 \text { years } \\
40-44 \text { years } \\
45-49 \text { years } \\
50-55 \text { years }\end{array}$ & $\begin{array}{l}17.3 \% \\
21.2 \% \\
44.2 \% \\
17.3 \%\end{array}$ & $\begin{array}{l}12.5 \% \\
37.5 \% \\
37.5 \% \\
12.5 \%\end{array}$ & 0.808 \\
\hline $\begin{array}{l}\text { Body mass index } \\
\text { Normal } \\
\text { Overweight } \\
\text { Obese } \\
\text { Morbidly obese }\end{array}$ & $\begin{array}{l}5.8 \% \\
23.1 \% \\
63.5 \% \\
7.7 \%\end{array}$ & $\begin{array}{l}- \\
50.0 \% \\
37.5 \% \\
12.5 \%\end{array}$ & 0.325 \\
\hline Smoker & $28.8 \%$ & $50.0 \%$ & 0.249 \\
\hline $\begin{array}{l}\text { Duration } \\
<1 \text { year } \\
1-4 \text { years } \\
5-9 \text { years } \\
10-14 \text { years } \\
>14 \text { years }\end{array}$ & $\begin{array}{l}11.5 \% \\
26.9 \% \\
25.0 \% \\
25.0 \% \\
11.5 \%\end{array}$ & $\begin{array}{l}- \\
37.5 \% \\
12.5 \% \\
37.5 \% \\
12.5 \%\end{array}$ & 0.577 \\
\hline $\begin{array}{l}\text { Treatment } \\
\text { Diet } \\
\text { OAD } \\
\text { Insulin } \\
\text { Insulin + OAD }\end{array}$ & $\begin{array}{l}1.9 \% \\
42.3 \% \\
17.3 \% \\
38.5 \%\end{array}$ & $\begin{array}{l}- \\
37.5 \% \\
25.0 \% \\
37.5 \%\end{array}$ & 0.912 \\
\hline $\begin{array}{l}\text { Regulation status } \\
\text { Good } \\
\text { Moderate } \\
\text { Insufficient }\end{array}$ & $\begin{array}{l}21.2 \% \\
42.3 \% \\
36.5 \%\end{array}$ & $\begin{array}{l}12.5 \% \\
50.0 \% \\
37.5 \%\end{array}$ & 0.824 \\
\hline
\end{tabular}

Lumbar spine and femoral BMD were measured. Lumbar BMD values were normal in $67.3 \%$ of patients, while $30.4 \%$ were osteopenic and $2.1 \%$ were osteoporotic. In terms of femoral BMD, $81.5 \%$ of patients were normal, $16.3 \%$ were osteopenic and $2.1 \%$ osteoporotic.

There was no statistical significance between demographic data (age, BMI, smoking status, duration of DM, retinopathy, nephropathy and neuropathy) or in BMD and bone turnover markers (CTX, homocysteine and osteocalcin) in the DM patients (Table 2, 3, 4).

Regulation status and BMD were compared in the DM patients, and the difference was not statistically significant ( $\mathrm{p}=0.54$ lomber $\mathrm{BMD}$ and $\mathrm{p}=0.82$ femur BMD). Regulation status and CTX levels $(\mathrm{p}=0.82)$, homocysteine $(\mathrm{p}=0.94)$ and osteocalcin $(\mathrm{p}=0.92)$ were also compared.

A statistical significance was observed between treatment modalities and osteocalcin levels $(p=0.006)$. Osteocalcin levels were abnormal in $76.4 \%$ of diabetic patients treated with OAD.
Table 3: Comparison of demographic status of high and normal osteocalcin groups in DM patients.

\begin{tabular}{l|ll|l}
\hline Variables & Normal & High & $\mathbf{p}$ \\
\hline Age & & & $\mathbf{0 . 3 9 5}$ \\
30-39 years & $16.0 \%$ & $17.6 \%$ & \\
$40-44$ years & $24.0 \%$ & $35.3 \%$ & \\
$45-49$ years & $38.7 \%$ & $41.2 \%$ & \\
50-55 years & $21.3 \%$ & $5.9 \%$ & \\
\hline Body mass index & & & $\mathbf{0 . 8 4 2}$ \\
Normal & $6.7 \%$ & $11.8 \%$ & \\
Overweight & $25.3 \%$ & $17.6 \%$ & \\
Obese & $61.3 \%$ & $64.7 \%$ & \\
Morbidly obese & $6.7 \%$ & $5.9 \%$ & \\
\hline Smoker & $28.0 \%$ & $11.8 \%$ & $\mathbf{0 . 2 2 2}$ \\
\hline Duration & & & $\mathbf{0 . 3 2 0}$ \\
<1 year & $13.3 \%$ & $23.5 \%$ & \\
1-4 years & $28.0 \%$ & $41.2 \%$ & \\
5-9 years & $25.3 \%$ & $23.5 \%$ & \\
10-14 years & $24.0 \%$ & $5.9 \%$ & \\
$>14$ years & $9.3 \%$ & $5.9 \%$ & \\
\hline Treatment & & & $\mathbf{0 . 0 0 6}$ \\
Diet & $2.7 \%$ & $11.8 \%$ & 0.154 \\
OAD & $45.3 \%$ & $76.5 \%$ & 0.020 \\
Insulin & $14.7 \%$ & - & 0.207 \\
Insulin + OAD & $37.3 \%$ & $11.8 \%$ & 0.042 \\
\hline Regulation & & & $\mathbf{0 . 9 2 6}$ \\
Good & $21.3 \%$ & $17.6 \%$ & \\
Moderate & $42.7 \%$ & $47.1 \%$ & \\
Insufficient & $36.0 \%$ & $35.3 \%$ & \\
\hline & & &
\end{tabular}

Table 4: Comparison of demographic status of high and normal homocysteine groups in DM patients.

\begin{tabular}{|c|c|c|c|}
\hline Variables & Normal & High & $\mathbf{P}$ \\
\hline Age & & & 0.178 \\
\hline $30-39$ years & $15.7 \%$ & $17.1 \%$ & \\
\hline 40-44 years & $27.5 \%$ & $24.4 \%$ & \\
\hline $45-49$ years & $31.4 \%$ & $48.8 \%$ & \\
\hline $50-55$ years & $25.5 \%$ & $9.8 \%$ & \\
\hline Body mass index & & & 0.357 \\
\hline Normal & $9.8 \%$ & $4.9 \%$ & \\
\hline Overweight & $19.6 \%$ & $29.3 \%$ & \\
\hline Obese & $66.7 \%$ & $56.1 \%$ & \\
\hline Morbidly obese & $3.9 \%$ & $9.8 \%$ & \\
\hline Smoker & $19.6 \%$ & $31.7 \%$ & 0.183 \\
\hline Duration & & & 0.565 \\
\hline$<1$ year & $19.6 \%$ & $9.8 \%$ & \\
\hline $1-4$ years & $31.4 \%$ & $29.3 \%$ & \\
\hline $5-9$ years & $25.5 \%$ & $24.4 \%$ & \\
\hline $10-14$ years & $15.7 \%$ & $26.8 \%$ & \\
\hline$>14$ years & $7.8 \%$ & $9.8 \%$ & \\
\hline Treatment & & & 0.580 \\
\hline Diet & $5.9 \%$ & $2.4 \%$ & \\
\hline OAD & $52.9 \%$ & $48.8 \%$ & \\
\hline Insulin & $13.7 \%$ & $9.8 \%$ & \\
\hline Insulin + OAD & $27.5 \%$ & $39.0 \%$ & \\
\hline Regulation & & & 0.940 \\
\hline Good & $19.6 \%$ & $22.0 \%$ & \\
\hline Moderate & $43.1 \%$ & $43.9 \%$ & \\
\hline Insufficient & $37.3 \%$ & $34.1 \%$ & \\
\hline
\end{tabular}

Lumbar spine BMD values were normal in $68.5 \%$ of the diabetic group and $57.6 \%$ of 
the control group. The difference was not statistically significant $(p=0.534)$. Femoral BMD values were normal in $81.5 \%$ of the diabetic group and $100 \%$ of the control group. There was a higher risk of osteopenia and osteoporosis in diabetic patients based on femoral BMD than in the control group $(\mathrm{p}=0.036)$.

Osteocalcin was normal in $81.5 \%$ of the diabetic group and $60.6 \%$ of the control group $(\mathrm{p}=0.016)$. Homocysteine values were higher in the control group than in the diabetics $(\mathrm{p}=0.018)$. No significant difference was observed in CTX values $(\mathrm{p}=0.12)$.

\section{DISCUSSION}

The aim of this study was to investigate the prevalence of osteoporosis and changes in bone turnover markers in diabetic premenopausal women.

The relationship of diabetes mellitus (DM) and osteoporosis is complex, and the pathogenesis of diabetic osteopenia is still unknown. Hormonal, vascular or mechanical factors may be involved ${ }^{7,8}$. Low turnover osteopenia associated with osteoblast dysfunction has been shown in patients with diabetes. Decreased bone formation is probably associated with a reduction in osteoblast activity. Insulin deficiency may cause abnormalities in bone and cartilage proteoglycan composition. Oxidative stress in diabetes may also play a role in the pathogenesis of osteoporosis ${ }^{9}$. Intensive treatment of diabetes can prevent osteoporosis. Elevated BMI and bone turnover markers and the presence of retinopathy are also important in the progression of diabetic osteopenia. No statistically significance was determined between demographic data (age, BMI, smoking status, duration of DM, retinopathy, nephropathy and neuropathy) and BMD and bone turnover markers (CTX, homocysteine and osteocalcin) in this study.

Some trials have reported duration of DM and insulin therapy ${ }^{5}$ are associated with an increased risk of fracture ${ }^{10}$, while others have determined no such association ${ }^{11}$. Recent studies have identified an increased risk of fracture in the proximal femur and foot in type $2 \mathrm{DM}$ patients despite high or normal hip BMD values ${ }^{4}$.

Regulation status of DM was classified based on the EASD database. Accordingly, $20.7 \%$ of patients had good regulation, $43.5 \%$ moderate and $35.9 \%$ insufficient. Regulation status and BMD were compared in the diabetic patients ( $\mathrm{p}: 0.54$ lomber BMD and p:0.82 femur BMD). According to the Fremantle Diabetes Study, regulation status is an important predictor of low BMD in men with type 1 DM. ${ }^{12}$. Regulation status has been shown to affect bone tissue irrespective of insulin therapy in several animal and human studies $^{13-15}$. According to one hypothesis, hyperglycemia reduces osteoblast functions by increasing osmolarity. Of the patients in the study, $4.3 \%$ were receiving a diabetic diet, $51.1 \%$ were being treated with oral antidiabetics (OAD), 12\% were receiving insulin and $32.6 \%$ were receiving insulin and OAD. There was a statistically significant relation between treatment modalities and osteocalcin levels. Osteocalcin levels were abnormal in $76.4 \%$ of diabetic patients treated with OAD. Previous studies have compared the incidence of osteoporosis with oral antidiabetic therapies. Schwartz et al. ${ }^{16}$ reported increased bone mineral loss in diabetic women treated with thiazolidinediones. The December 2006 ADOPT trial demonstrated a higher risk of osteoporosis in patients treated with rosiglitazone than in those treated with metformin or glyburide ${ }^{17}$. In Takeda et al. ${ }^{18}$ trial, a higher risk of osteoporosis was determined in 24,000 patients treated with pioglitazone. In the light of these studies, thiazolidinediones, and especially pioglitazone, may be included among the risk factors for osteoporosis.

Osteopenia and osteoporosis levels based on femoral BMD were higher in diabetic patients in this study, while homocysteine values were higher in the control group than in the diabetics. One recent study reported that although elderly Type 2 diabetic women had higher femoral and lumbar BMD than the control group, their CTX and osteocalcin levels were significantly lower ${ }^{19}$. Studies of diabetic mice have reported a decrease in the numbers of osteoblasts and osteoclasts ${ }^{20}$. These trials showed a low bone turnover in diabetic 
patients, such as those using glucocorticoids $^{21-22}$. A decrease in bone resorption leads to a higher BMD values by age but increased bone fragility predisposing to injury.

In conclusion; our results demonstrate that DM adversely affects femoral BMD and bone turnover markers such as homocysteine. Some DM pharmacotherapies have side-effect on markers such as osteocalcin. Although some reports in literature have suggested that regulation of DM may affect the risk of osteoporosis, our results do not support that. Diabetes affects bone quality and fragility, so BMD values may not reflect the risk of fracture. BMD measurement might not be a gold standard for osteoporosis in diabetic patients.

\section{REFERENCES}

1. Van Daele P, Stolk RP, Burger H, Algra D, Grobbee DE, Horman A, Birkenhager JC, Pols HA. Bone density in non insulin dependent diabetes. The Rotterdam Study. Annals of Internal Medicine 1995; 122: 409-14.

2. Sosa M, Dominguez M, Navarro MC, Segarra MC, Hernandez D, De Pablos P, Betancor P. Bone mineral metabolism is normal in non-insulin dependent diabetes mellitus. Journal of Diabetes and Its Complications 1996; 10: 201-5.

3. Isaia $\mathrm{G}$, Bodrato L, Carlevatto V, Mussetta M, Salamano G, Molinatti GM. Osteoporosis in type 2 diabetes. Acta Diabetol Lat 1987; 24: 305-10.

4. Schwartz AV, Sellmeyer DE, Ensrud KE.Older women with diabetes have an increased risk of fracture: a prospective study. J Clin Endocrinol Metab 2001; 86: 32-8.

5. Nicodemus KK, Folsom AR (2001) Type 1 and type 2 diabetes and incident hip fractures in postmenopausal women. Diabetes Care 24: 1192-7.

6. Sorensen MG, Henriksen K. Biochemical markers in preclinical models of osteoporosis $\mathrm{Bi}$ omarkers, May-June 2007; 12:
266.

7. Piepkorn B, Kann P, Forst T, Andreas J, Pfutzner A, Beyer J. Bone mineral density and bone metabolism in diabetes mellitus. Horm Metab Res 1997; 29:584-91.

8. Kemink SAG, Hermus ARMM, Swinkels LMJW, Lutterman JA, Smals AGH. Osteopenia in insulin-dependent diabetes mellitus: prevalence and aspects of pathophysiology. J Endocrinol Invest 2000; 23: 295-303.

9. Valéria MG. Duarte, Ana MO. Ramos, Luciana A. Rezende, Ulisvaldo BO. Macedo, José BrandãoNeto, Maria G. Almeida and Adriana A. Rezende. Osteopenia: a bone disorder associated with diabetes mellitus. J Bone Miner Metab 2005; 23: 58-68.

10. Meyer HE, Tverdal A, Falch JA. Risk factors for hip fracture in middle-aged Norwegian women and men. Am J Epidemiol 1993; 137: 1203-11.

11. Heath H 3rd, Melton LJ 3rd, Chu CP. Diabetes mellitus and risk of skeletal fracture. $\mathrm{N}$ Engl $\mathrm{J}$ Med 1980; 303: 567-70.

12. Albright F, Reifenstein EC. Parathyroid Glands and Metabolic Bone Disease: Selected Studies. Williams and Wilkins, Baltimore 1948; 150-64.

13. Kemink SAG, Hermus ARMM, Swinkels LMJW, Lutterman JA, Smals AGH. Osteopenia in insulin-dependent diabetes mellitus: prevalence and aspects of pathophysiology. J Endocrinol Invest 2000; 23: 295-303.

14. Waud CE, Marks SC, Lew R, Baran DT. Bone mineral density in the femur and lumbar vertebrae decreases after 12 weeks of diabetes in spontaneously diabeticprone BB-Worcester rats. Calcif Tissue Int 1994; 54: 237-40.

15. Koyama I, Yakushijin M, Nakajima, T, Hokari S, Kawai S, Oh-Ie K, Inoue I, Negishi K, Katayama S, Komoda T. Reduced alkaline phosphatase activity in diabetic rat bone: a re-evaluation. Comparative 
Biochem Physiol 1998; 121: 41723.

16. Schwartz AV, Sellmeyer DE, Vittinghoff E, Palermo L, LeckaCzernik B, Feingold KR, Strotmeyer ES, Resnick HE, Carbone L, Beamer BA, Park SW, Lane NE, Harris TB, Cummings $\mathrm{SR}$, for the Health, Aging and Body Composition (Health ABC) Study Thiazolidinedione use and bone loss in older diabetic adults. J Clin Endocrinol Metab 2006; 91: 3349-35.

17. Kahn SE, Haffner SM, Heise MA, Herman WH, Holman RR, Jones NP, Kravitz BG, Lachin JM, O’Neill MC, Zinman B, Viberti G: Glycemic durability of rosiglitazone, metformin, or glyburide monotherapy. N Engl J Med 2006; 355: 2427-43.

18. Takeda: Observation of an increased incidence of fractures in female patients who received longterm treatment with ACTOS (pioglitazone $\mathrm{HCl}$ ) tablets for type 2 diabetes mellitus (Letter to Health Care Providers), March 2007.

19. Gerdhem P, Isaksson A, Akesson $\mathrm{K}$, Obrant KJ. Increased bone density and decreased bone turnover, but no evident alteration of fracture susceptibility in elderly women with diabetes mellitus. Osteoporos Int 2005; 16:1506-12.

20. Verhaeghe J, van Herck E, Visser WJ, Suiker AM, Thomasset M, Einhorn TA, Faierman E, Bouillon $\mathrm{R}$. Bone and mineral metabolism in $\mathrm{BB}$ rats with long-term diabetes. Decreased bone turnover and osteoporosis. Diabetes 1990; 39: 477 82.

21. Weinstein RS, Jilka RL, Parfitt AM, Manolagas SC. Inhibition of osteoblastogenesis and promotion of apoptosis of osteoblasts and osteocytes by glucocorticoids: potential mechanisms of their deleterious effects on bone. J Clin Invest 1998; 102: 274-82.

22. Dalle Carbonare L, Arlot ME, Chavassieux PM, Roux JP, Portero
NR, Meunier PJ. Comparison of trabecular bone microarchitecture and remodeling in glucocorticoidinduced and postmenopausal osteoporosis. J Bone Miner Res 2001; 16: 97-103. 